DE DE GRUYTER

OPEN
Journal of Intercultural Management

Vol. 6, No. 2, April 2014, pp. 35-47

DOI 10.2478/joim-2014-0010

\author{
Aleksandra Radziszewska \\ Czestochowa University of Technology
}

\title{
Intercultural dimensions of entrepreneurship
}

\begin{abstract}
Entrepreneurship is increasingly being recognized as an important factor for economic growth and the regeneration of economies. The importance of different cultural dimensions and their effect on entrepreneurship has been noted in a number of studies. This paper focuses on national culture as a determinant of entrepreneurship, and family firms' creation. National culture is important for interpreting for the differences of entrepreneurial activities across countries. The different dimensions of national culture affect different aspects of entrepreneurship and opportunities family firms' creation. The paper describes the effect of national culture on entrepreneurship in different cultural communities using the Hofstede's model and GLOBE study.
\end{abstract}

Key words: entrepreneurship, culture, family firms, GLOBE study, culture dimensions

\section{Introduction}

The decision to start a venture has both cultural and economic dimensions. Starting a business is an entrepreneurial act and a means for generating selfemployment and income, and thus is an economic act. However, the process of establishing a business often has important social dimensions. The important role that culture plays as a construct in some aspects of entrepreneurship has been noted in the literature. It is possible to find different types and levels of entrepreneurial opportunities and resources across cultures. Entrepreneurship is defined as a field that is "concerned with the discovery and exploitation of profitable opportunities" [Shane S., Venkataraman S., 2000, pp. 217-226].

The entrepreneur is seen as an independent, risk-taking maverick who boldly organizes the people and resources necessary for creating new business ventures. For such a role to emerge within a culture, at least two social conditions must exist: entrepreneurs must be granted social acceptance so that 
the activities associated with new venture formation are accepted as legitimate and socially beneficial, and entrepreneurs must be able to gain access to and control of financial, material and educational resources necessary to initiate new ventures [Backes-Gellner U., Werner A., 2007, pp. 173-190].

Entrepreneurship in cross-cultural context refers to the entrepreneurship of recent cultural communities by the means of starting a business or engaging in self-employment. The explanation of different entrepreneurial activity across nations and regions is linked to differences in values and beliefs between potential entrepreneurs and populations as a whole. It suggests that in a predominantly non-entrepreneurial culture, a clash of values between groups may drive potential self-employed into actual self-employment [Baum J. et al., 1993, pp. 499-512].

\section{Cultural diversify and entrepreneurship}

Cultures can be described according to specific characteristics or categorized into value categories or dimensions of national culture. Categories for national and organizational culture in the example of cross-cultural studies provide to describe how culture may determine the way people act, think and feel. The concept of culture has found their equivalents in the organizational literature where history, heroes, artefacts and assumptions make up the cultural fabric of companies [Schein E., 1992, p. 9]. Culture is the glue that binds groups together. Without cultural patterns, organized systems of significant symbols, people would have difficulty living together. The anthropologist Clifford Geertz views culture as a set of control mechanisms - plans, recipes, rules, instructions for governing behaviour [Geertz C., 1973, p. 44]. Culture includes shared beliefs, attitudes, norms, roles and values found among members of a particular community who live during the same historical period in a specific geographic region [Triandis H., 1995, p. 89].

Geert Hofstede describes culture as 'the collective programming of the mind' [Hofstede G.,2001, p. 10]. Hofstede developed a model of five dimensions of national culture that helps to explain basic value differences. This model distinguishes cultures according to five dimensions: Power Distance, Individualism-Collectivism, Masculinity-Femininity, Uncertainty Avoidance, and Long-Term Orientation. The dimensions are measured on a scale from 0 to 100 . The model is based on quantitative research and gives scores for 75 countries and regions. Hofstede describes over 200 external comparative studies and replications that have supported his indexes. The dimensions can be used to explain differences in people's needs and motives, communication styles, language structure, metaphors and concepts used in advertising and in literature across different countries [Hofstede G., 2001]. Power distance is the extent to which less powerful members of a society accept that power is 
distributed unequally. In large power-distance cultures (e.g. France, Belgium, Portugal, Italy, Spain, Russia and the whole of Asia and South America), everyone has their rightful place in society and there is respect for elders and people in authority. There are dependence relationships between young and old, parents and children, and teachers and students. Demonstration of social position is important, so ownership of status objects to demonstrate one's position in society is more important in cultures of large power distance than in cultures of small power distance (e.g. Great Britain, Germany, the Netherlands and Scandinavia). In individualistic cultures, people look after themselves and their immediate family only and want to differentiate themselves from others. There is a need for privacy. In collectivistic cultures people belong to ingroups who look after them in exchange for loyalty. People prefer to conform to the norms adopted by others instead of differentiating themselves from others. In individualistic cultures the person is viewed as an independent. In collectivistic cultures individuals are fundamentally dependent on each other. The self cannot be separated from others and the surrounding social context. Hofstede suggested a correlation between collectivism and highcontext in cultures. In collectivistic cultures, information flows more easily among members of groups and there is less need for explicit communication than in individualistic cultures [De Mooij M., 1998, p. 87]. The anthropologist Edward Hall distinguished patterns of culture according to context, space, time, and information flow. The concept relates to the balance between the verbal and the non-verbal communication. In a low context culture spoken language carries the emphasis of the communication. The concept of context is useful for understanding differences in communication across cultures because it explains the degree of directness of communication. Information in a low-context communication message is carried in the explicit code of the message. Examples include Australia and the Netherlands. In a high context culture verbal communications tend not to carry a direct message. In a highcontext communication message most of the information is either part of the context or internalized in the person. So with a high context culture hidden cultural meaning needs to be considered. Examples of a high context cultures include Japan and some Arabic nations [Hall E., Reed Hall M., 1990]. North Americans and Northern Europeans are individualists; in the south of Europe people are moderately collectivist. Asians, Latin Americans and Africans are collectivists. In masculine cultures the dominant values are achievement and success. The dominant values in feminine cultures are caring for others and quality of life. In masculine cultures status products and brands are important for demonstrating success. Men and women have distinct roles. Feminine cultures have a people orientation. Examples of masculine cultures include the 
US, Great Britain, Germany, Italy, Mexico and Japan. Examples of feminine cultures include the Netherlands, Scandinavian countries, Portugal, Spain, Chile and Thailand. Uncertainty avoidance is the extent to which people feel threatened by uncertainty and ambiguity and try to avoid them. In cultures of strong uncertainty avoidance, there is a need for rules, rituals and formality to structure life. Competence is a strong value resulting in belief in experts, as opposed to weak uncertainty avoidance cultures characterized by belief in generalists. In weak uncertainty avoidance cultures people tend to be more innovative and less bureaucratic. Southern and Eastern European countries as well as Japan score high on uncertainty avoidance, while England, Scandinavia and Singapore score low. The fifth dimension, long term orientation versus short term orientation, distinguishes between long-term thinking and short-term thinking. Other elements include pragmatism, perseverance and thrift. This dimension distinguishes mainly between Western short-term oriented and East Asian long-term oriented cultures. In Europe, the differences are small but in some cases significant. The Netherlands and Norway score relatively high, and Spain scores lowest [Hofstede G., 2001].

Cultural differences have direct influence on entrepreneurial orientation and entrepreneurial behaviors among member of particular cultural community. The general consequence of low power distance is greater access to resources and entrepreneurial opportunities restricted opportunities - more entrepreneurial initiatives. High power distance makes access to resources and entrepreneurial opportunities restricted hence fewer entrepreneurs emerge. Low uncertainty has the consequence of increased willingness to take risks - increased scope for individual initiative - more initiation of entrepreneurial ventures. High uncertainty leads to general avoidance of risk. Individualistic cultures prize individual initiative and autonomy. Loyalty to organizations is relatively low, taking a back seat to individual interests. As a consequence, independent entrepreneurial behavior is valued and supported by social norms as a means of achieving personal goals. Low individualism has the consequence of fewer individual entrepreneurs and fewer entrepreneurial ventures emerging. High individualism leads to individual entrepreneurial activities valued resulting in more entrepreneurs and entrepreneurial ventures. In masculine societies, the material success achieved through successful entrepreneurial ventures is valued and entrepreneurs who attain such success are recognized and esteemed. Conversely, in relatively feminine cultures, achievement motivation, at least in the material sense, is relatively weak and success is defined in terms of pleasant human relationships. Consequently, it is presumed that more individuals will be attracted to entrepreneurship as a means of achieving material benefits and social position in masculine cultures while there will be less interest in 
entrepreneurial activities in feminine cultures. Low masculinity leads to less interest in entrepreneurship as a source of achievement and wealth while high masculinity leads to greater focus on entrepreneurship as a source of achievement and wealth [Hofstede G., 2001].

\section{Cultural dimensions according GLOBE study}

One of the first and most influential studies on cultural differences was done by Hofstede. Apart from Hofstede, several other researchers through similar and more extensive studies proposed different scales. The GLOBE project is also the new scale that has been widely accepted and includes a few complementary dimensions. Research by the GLOBE project extends Hofstede's assessment and offers a broader understanding for culture dimensions. The GLOBE (Global Leadership and Organizational Behavior Effectiveness) project used data collected from 18,000 managers in 62 countries to identify nine dimensions that explain cultural differences, including those identified by Hofstede. GLOBE's first major achievement is a comprehensive description of how cultures are different or similar from one another. GLOBE established nine cultural dimensions that make it possible to capture the similarities and/or differences in norms, values, beliefs -and practices-among societies [House R. et al, 2002, pp. 3-10]:

- Assertiveness: A high value on assertiveness means a society encourages toughness, assertiveness, and competitiveness. Low assertiveness means that people value tenderness and concern for others over being competitive.

- Future orientation: Similar to Hofstede's time orientation this refers to the extent to which a society encourages and rewards planning for the future over short term, results and quick gratification

- Uncertainty avoidance: As with Hofstede's study, this is a degree to which members of a society feel uncomfortable with uncertainty and ambiguity

- Gender differentiation: This dimension refers to the extent to which a society maximizes gender role differences. In countries with low gender differentiation such as Denmark, women typically have a higher status and stronger role in decision making. Countries with high gender differentiation accord men higher social, political and economic status.

- Power distance: This dimension is the same as Hofstede's and refers to the degree to which people expect and accept equality or inequality in relationships institutions.

- Societal collectivism: This term is defined as the degree to which practices in institutions such as schools, businesses and other social organizations encourage a tightly knit collectivist society in which people are an important part of a group, or highly individualistic society.

- Individual collectivism: Rather than looking at how societal organizations 
favor individualism versus collectivism this dimension looks at the degree to which individuals take pride in being members of a family, close circle of friends team, or organization.

- Performance orientation: a society with a high performance orientation places high emphasis on performance and rewards people for performance improvements and excellence. A low performance orientation means people pay less attention to performance and more attention to loyalty belonging and background.

- Humane orientation: The final dimensions refers to the degree to which a society encourages and rewards people for being fair, altruistic generous, and caring. A country high on humane orientation places high value of helping others and being kind. A country low on this orientation expects people to take care of themselves. Self enhancement and gratification is of high importance.

Cultural dimensions according GLOBE study and polish culture assessment have been presented in table 1 .

Table 1. Cultural dimensions according GLOBE study

\begin{tabular}{|l|l|l|l|}
\hline $\begin{array}{l}\text { Cultural Dimen- } \\
\text { sion }\end{array}$ & Description & \multicolumn{2}{|l|}{$\begin{array}{l}\text { Polish culture } \\
\text { assessment }\end{array}$} \\
\hline $\begin{array}{l}\text { Scale range }=1 \text { to } 7 \\
\text { Number of countries = } 62\end{array}$ & Practices & Values \\
\hline Power Distance & $\begin{array}{l}\text { The degree to which members of a collective expect } \\
\text { power to be distributed equally. }\end{array}$ & 5,09 & 3,19 \\
\hline $\begin{array}{l}\text { Uncertainty } \\
\text { Avoidance }\end{array}$ & $\begin{array}{l}\text { The extent to which a collective relies on social norms, } \\
\text { rituals, and procedures to alleviate the unpredictabil- } \\
\text { ity of future events. }\end{array}$ & 3,71 & 4,75 \\
\hline $\begin{array}{l}\text { Humane Orien- } \\
\text { tation }\end{array}$ & $\begin{array}{l}\text { The degree to which a collective encourages and re- } \\
\text { wards individuals for being fair, altruistic, generous, } \\
\text { caring and kind to others. }\end{array}$ & 3,67 & 5,32 \\
\hline $\begin{array}{l}\text { Institutional } \\
\text { Collectivism }\end{array}$ & $\begin{array}{l}\text { The degree to which organizational and societal in- } \\
\text { stitutional practices encourage and reward collective } \\
\text { distribution of resources and collective action. }\end{array}$ & 4,51 & 4,24 \\
\hline $\begin{array}{l}\text { In-Group } \\
\text { Collectivism }\end{array}$ & $\begin{array}{l}\text { The degree to which individuals express pride, loyalty } \\
\text { and cohesiveness in their organizations or families }\end{array}$ & 5,55 & 5,59 \\
\hline Assertiveness & $\begin{array}{l}\text { The degree to which individuals are assertive, con- } \\
\text { frontational and aggressive in their relationships with } \\
\text { others. }\end{array}$ & 4,11 & 3,95 \\
\hline $\begin{array}{l}\text { Gender Egali- } \\
\text { tarianism }\end{array}$ & $\begin{array}{l}\text { The degree to which a collective minimizes } \\
\text { gender inequality. }\end{array}$ & 3,94 & 4,53 \\
\hline $\begin{array}{l}\text { Future Orienta- } \\
\text { tion }\end{array}$ & $\begin{array}{l}\text { The extent to which individuals engage in future } \\
\text { orientated behaviours such as delaying gratification, } \\
\text { planning and investing in the future }\end{array}$ & 3,23 & 5,17 \\
\hline
\end{tabular}




\begin{tabular}{|l|l|l|l|}
\hline $\begin{array}{l}\text { Performance } \\
\text { Orientation }\end{array}$ & $\begin{array}{l}\text { The degree to which a collective encourages and re- } \\
\text { wards group members for performance improvement } \\
\text { and excellence. }\end{array}$ & 3,96 & 6,06 \\
\hline
\end{tabular}

Source: House R., Hanges P., Javidan M., Dorfman P. (2004), Culture, Leadership and Organizations: the GLOBE Study of 62 Societies, Thousand Oaks: Sage Publications.

They can be classified into the categories of traditionalistic culture and modernistic culture. Traditionalistic cultures emphasize the value of traditional family, economic behavior tends to emphasize cooperation and team work. People in traditionalistic culture can obtain plenty of social and emotional support from their extended family and in-group social circle, and interpersonal relationship are built on trust. Additionally, traditionalistic cultures emphasize the value of deference to authority as well as to a centralized economic system. On the other hand, modernistic cultures emphasize individual freedom, personal achievement, self-expression, subjective wellbeing and quality of life. The economic behavior associated with modernistic culture often entails large scale operation and profit maximization. People in modernistic cultures are not only conscientiously managing their time in order to utilize it efficiently, but they also emphasize the presence and the future. Finally, the uncertainties associated with a decentralized economic system combined with a differentiated division of labor and complex industrial environment entail measures to make the environment more predictable in modernistic cultures [Hill, J. S., 2000, pp. 3-21].

Cultural dimensions in the GOLBE study related with traditional societies are: in-group collectivism, humane orientation, and power distance. Other dimensions are related to modernistic cultures: performance orientation, future orientation and uncertainty avoidance (Table 2).

Table 2. Cultural dimensions of traditional and modernistic cultures

\begin{tabular}{|l|l|}
\hline Traditional cultures & Modernistic cultures \\
\hline $\begin{array}{l}\text { in-group collectivism, } \\
\text { humane orientation, } \\
\text { power distance }\end{array}$ & $\begin{array}{l}\text { performance orientation, } \\
\text { future orientation } \\
\text { uncertainty avoidance }\end{array}$ \\
\hline
\end{tabular}

Source: Hill, J. S. (2000) 'Modern-Traditional Behaviors', Journal of Transnational Management Development, vol. 5, no. 3, pp. 3-21.

Traditionalistic culture is conceptually related to in-group collectivism, humane orientation and power distance while modernistic culture is conceptually related to future orientation, performance orientation and uncertainty avoidance. 


\section{Entrepreneurship in different cultures}

Enhancing entrepreneurship is viewed in the light of economic growth, job-creation and competitiveness. Countries differ considerably in the level of entrepreneurial activity. National culture can be defined as a country's shared practices and values [House et al., 2004, p.21]. Cultural values tell us how members of a culture think their culture should be whereas cultural practices are related to how people go about doing things. Some specific cultural dimensions in the GLOBE study are relevant for entrepreneurship. Culture has a direct manifestation in the behavior of people belonging to a specific culture. It influences the personal values of individuals, and furthermore, influences their behaviors. Thus, national culture can support or impede entrepreneurial behavior at the individual level [Hayton et al., 2002, pp. 33-52.]. In other words, culture indicates the degree to which a society considers entrepreneurial behaviors such as risk-taking, growth-orientation, innovativeness, opportunity recognition and exploitation to be desirable.

Cultural factors frequently related to entrepreneurship activities include individualism, power distance, and uncertainty avoidance. Geert Hofstede pointed out that greater opportunities for entrepreneurship typically exist in long-term oriented cultures such as Korea, Taiwan, China and Japan, and cultures that put less value on power distance would favor entrepreneurship. In individualistic cultures we can find more entrepreneurs than we can find in collectivistic cultures [Hofstedte G., 2001].

In-group collectivism measures the degree to which individuals express pride, loyalty and cohesiveness in their groups and families [House et al., 2002, pp. 3-10]. In high in-group collectivistic societies, people depend heavily on their special personal relationships, and emphasize group goals. In-group collectivism has been related to entrepreneurial activities. It is assumed to be negatively related to entrepreneurship, because entrepreneurship is an activity of enterprising individuals who are individually rewarded. Entrepreneurship includes taking personal risks associated with market entry and innovation. Successful entrepreneurs must have characteristics such as creativity and the ability to develop new and unique ideas, characteristics which are typically associated with individualistic orientations. These arguments favor the position that collectivism is negatively related to entrepreneurial activities [Hayton et al., 2002, pp. 33-52.]. It has been argued that collectivism helps entrepreneurship because collectivistic societies provide more social support and resources. For example, families in collectivistic societies tend to be more helpful in providing the needed resources for one's entrepreneurial endeavors and the needed social security in the event that things do not work out. Moreover, collectivistic orientation fosters commitment and sacrifice 
amongst employees and provides a protective environment that minimizes the uncertainty associated with business creation and innovation implementation [Freytag A., Thurik R., 2007, pp. 117-131].

Humane orientation is the degree to which societies encourage and reward individuals for being fair, altruistic, friendly, generous, caring, and being kind to others. In high humane oriented societies, people within a close circle receive material, financial, and social support. In addition, it means that there is a high degree of compassion and help for people in the immediate neighborhood, and also a certain conservative attitude and pressure for conformism towards people. Humane orientation helps the development of entrepreneurship because it provides resources and support in the event that things go wrong within the immediate environment of the entrepreneur. Thus, entrepreneurs will feel supported and sufficiently secure to start and develop a business. In addition, humane orientation allows for errors and failures. This means that the social environment will still be supportive and people will not be ostracized when they fail. Moreover, people who had failed may actually be encouraged to try again. Given that the fear of failure is one of the reasons why people do not start a business even though they might want to, there may be a direct effect between humane orientation and entrepreneurial activity [Stephan, U., Uhlaner, L., 2010, pp. 1347-1364].

Power distance measures the degree to which members of a society expect and agree that power should be unequally distributed. Societies with higher power distance tend to be restricted to limited upward social mobility, localized information, and social status which is linked to established power relationships. Entrepreneurial activity should be higher in low power distance countries. In high power distance cultures is little acceptance for the initiatives and innovations created by new business ventures. However, power distance can have a positive impact on entrepreneurial behavior as well. Power distance can affect entrepreneurial activity positively because the only way to be independent is to be an entrepreneur. Entrepreneurship can be used as one of the tools to struggle for independence and to increase one's power position [House et al., 2002, pp. 3-10].

Performance orientation refers to the extent to which a society encourages and rewards its members for performance improvement and excellence. This dimension is clearly based on the achievement and is positively related to high quality entrepreneurship. [Hayton et al., 2002, pp. 33-52.].

Future orientation addresses the degree to which individuals engage in future-oriented behaviors such as planning, investing in the future, and delaying gratification. Countries with high future orientation have a strong capability and willingness to imagine future contingencies, formulate future 
goal states, seek to achieve higher goals, and to develop strategies for meeting their future aspirations. Countries high in future orientation should have more high quality entrepreneurial activity. Individuals anticipate potential future opportunities in a changing environment and will tend to think of investing now in order to reap future profits. Second, future orientation also implies that one thinks about the future because one is worried about the future. Future orientation is highly related to uncertainty avoidance [Shane S., Venkataraman S., 2000, pp. 217-226].

People in high uncertainty avoidant countries are threatened by new and unpredictable future situations. Members of such cultures tend to avoid uncertainty by reliance on social norms, rituals, and bureaucratic practices to alleviate the unpredictability of future events [House et al., 2002, pp. 3-10]. Such practices include formalized interaction, documentation and planning, as well as resistance to risk, change and new product development. Such practices may suggest that high uncertainty avoidant countries have low level of entrepreneurship. High uncertainty avoidance implies long-term planning, environment scanning and the prediction of future developments. Thus, uncertainty avoidance directly addresses the uncertainties associated with business venturing, for example, by reducing the risk in business and creating a safe environment. In addition, high uncertainty avoidance is also helpful in increasing the quality of products and services, for continuous improvement and so on (this is exactly the cases of Japan and Germany). Thereby, uncertainty avoidance leads to new products development and business growth [Hayton et al., 2002, pp. 33-52].

Relationship between cultural dimensions and entrepreneurship orientation an behaviors has been presented in the table 3 .

Table 3. Relationship between cultural dimensions and entrepreneurship

\begin{tabular}{|l|l|}
\hline Cultural dimensions & Influence on entrepreneurship \\
\hline Long term orientation & positive \\
\hline Short term orientation & negative \\
\hline Low power distance & positive \\
\hline High power distance & $\begin{array}{l}\text { Negative - new family firms creation } \\
\text { Positive- Entrepreneurship can be used as one of the tools to } \\
\text { struggle for independence and to increase one's power position, } \\
\text { because the only way to be independent is to be an entrepreneur. }\end{array}$ \\
\hline Individualism & positive \\
\hline
\end{tabular}




\begin{tabular}{|l|l|}
\hline Collectivism & $\begin{array}{l}\text { Negative- entrepreneurship is associated with individualistic } \\
\text { orientations }\end{array}$ \\
$\begin{array}{l}\text { Positive - collectivistic societies provide more social support, fam- } \\
\text { ilies in collectivistic societies tend to be more helpful in providing } \\
\text { the needed resources for one's entrepreneurial endeavors }\end{array}$ \\
\hline Human orientation & positive \\
\hline Performance orientation & positive \\
\hline $\begin{array}{l}\text { Luture orientation } \\
\text { ance }\end{array}$ & positive \\
\hline $\begin{array}{l}\text { High uncertainly avoid- } \\
\text { ance }\end{array}$ & positive \\
\hline $\begin{array}{l}\text { Negative- formalized interaction, documentation and planning, } \\
\text { as well as resistance to risk, change and new product develop- } \\
\text { ment. }\end{array}$ \\
\hline \\
\hline
\end{tabular}

Source: own elaboration on basis House R., Javidan M., Hanges P., Dorfman P. (2002) 'Understanding cultures and implicit leadership theories across the globe: an introduction to project GLOBE', Journal of Word Business, vol. 37, pp. 3-10.

National culture plays a different role on entrepreneurial activities. The practices that are successful in one culture may very well be dysfunctional in other cultures. The most positive influence on entrepreneurship have such values as: long term orientation, low power distance, individualism, human orientation, performance orientation, future orientation, and low uncertainly avoidance.

Entrepreneurship refers to the willingness to commit significant resources to some uncertain opportunities. A high risk taking propensity is often attributed to entrepreneurs. Individuals differ in risk aversion and people with less risk averse become entrepreneurs. Uncertainty is particularly relevant for start-up entrepreneurs because they cannot know the full range of possible outcomes. Entrepreneurs have a strong need for achievement. Achievement motivation is the most important factor that contributes in explaining of growth rates and entrepreneurship. Entrepreneurs who have high achievement motivation have a tendency towards risk taking. Need for achievement remains a key force in entrepreneurial success. An individual with a high need for achievement takes personal responsibility for decisions, set goals and accomplish them through own effort. Individualism is associated with the willingness of people to violate norms and their level of achievement motivation.

Of all culture dimensions, the one most directly associated entrepreneurship is individualism. The activities of the entrepreneur are quintessentially 
individualistic. Individualistic cultures prize individual initiative and autonomy. Individual rather than group beliefs and needs predominate. Independent entrepreneurial behavior is valued and supported by social norms as a means of achieving personal goals. As a result, many individuals are likely to be attracted to entrepreneurship. Collectivist cultures tend to discourage individual initiative and rely upon the group. In this social context, there is a preference for working in large organizations. As a consequence, collectivist societies are less likely to reward individual entrepreneurial efforts and fewer individuals are likely to aspire to the role of entrepreneur. Culture refers to an interpretive framework through which individuals make sense of their own behaviour. Members of the particular community learn shared values through different stages of socialization processes of their lives in institutions such as family, religion, formal education, and the society as a whole. Cultural values were linked to the self-concept, cognitions, and personality. Culture comprises each individual's assumptions, adaptations, perceptions and learning.

Culture is important in any dimension of entrepreneurship as it determines the attitudes of individuals towards the initiation of entrepreneurship. Different cultures perceive entrepreneurship and entrepreneurship opportunity differently and there are significant differences across cultures in motivations to launch a new business. A culture that contains pro-entrepreneurial values will serve as an incubator in the entrepreneurship process. In contrast, in societies where entrepreneurship has become tainted with charges of profiteering, speculation, violence and criminality, entrepreneurship has not been well received. This negativity may be an inevitable stage of transitional development but may also foster strong and durable anti-entrepreneurial values. Cross-national differences in levels of entrepreneurial activity may be explained by a wide range of economic cultural factors. The entrepreneur may be driven not only by economic motives but also by psychological motives like the desire to innovate and create new products.

\section{Conclusions}

This paper has attempted to explore the interaction between culture and entrepreneurship by comparing the cultural attributes and entrepreneurial behavior. Some cultures are more conducive for entrepreneurship than others, considering the different cultural heritages and dimensions. Factors encouraging and discouraging entrepreneurship vary not only across countries, but the regions and cultures as well. Every culture needs then a detailed research in order to carefully recognize those factors and work at the programs that perfectly match the individual situations. Countries differ considerably in the level of entrepreneurial activity. Knowing the causes for such crosscountry differences is important for practice as well as theory. Culture has a 
direct manifestation in the behavior of people belonging to a culture. National culture can support or impede entrepreneurial behavior at the individual level. Culture indicates the degree to which a society considers entrepreneurial behavior such as opportunity recognition and exploitation to be desirable. In this view, a culture that supports entrepreneurship produces more people with entrepreneurial potential and, as a consequence, more entrepreneurial activity.

\section{Bibliography}

Baum, J.R., Olian J.D., Erez M., Schnell E.R., Smith K.G., Sims H.P., Scully J.S., Smith K.A. (1993), 'Nationality and work role interactions: a cultural contrast of Israeli and US entrepreneurs' versus managers' needs', Journal of Business Venturing, vol. 8, no. 6, pp. 499-512.

Backes-Gellner U., Werner A. (2007), 'Entrepreneurial Signaling via education: success factor in innovative start-ups', Small Business Economics, vol. 29, no. 2, pp. 173-190.

De Mooij M. (1998), Global Marketing and Advertising. Understanding Cultural Paradoxes, Thousand Oaks: Sage Publications.

Freytag, A., Thurik, R. (2007), 'Entrepreneurship and its determinants in a crosscountry setting', Journal of Evolutionary Economics, vol. 17, pp. 117-131.

Geertz C. (1973), The Interpretation of Cultures, New York: Basic Books.

Hall E.T., Reed Hall M. (1990), Understanding Cultural Differences. Germans, French and Americans, Yarmouth, Maine: Intercultural Press.

Hayton, J.C., George, G., Zahra, S.A. (2002), 'National culture and entrepreneurship: A review of behavioral Research', Entrepreneurship Theory and Practice, vol. 26, no.4, pp. 33-52.

Hill, J.S. (2000), 'Modern-Traditional Behaviors', Journal of Transnational Management Development, vol. 5, no. 3, pp. 3-21.

House R., Hanges P., Javidan M., Dorfman P. (2004), Culture, Leadership and Organizations: the GLOBE Study of 62 Societies, Thousand Oaks: Sage Publications.

House R., Javidan M., Hanges P., Dorfman P. (2002), 'Understanding cultures and implicit leadership theories across the globe: an introduction to project GLOBE', Journal of Word Business, vol. 37, pp. 3-10.

Hofstede G. (2001), Cultures and Organizations. Software of the Mind, London: McGrawHill.

Schein E. (1992), Organizational Culture and Leadership: A Dynamic View, San Francisco: Jossey-Bass.

Shane S., Venkataraman S. (2000), 'The promise of entrepreneurship as a field of research', The Academy of Management Review, vol. 25, no. 1, pp. 217-226.

Stephan, U., Uhlaner, L. M. (2010), 'Performance-based vs. socially supportive culture: A cross-national study of descriptive norms and entrepreneurship', Journal of International Business Studies, vol. 41, no. 8, pp. 1347-1364.

Triandis H.C. (1995), Individualism \& Collectivism, Boulder: West View Press. 